\title{
Interaction between the state and the church in the interests of preserving the spiritual health of civil society: an analysis of the Russian experience
}

\author{
Vorontsov A.L. \\ Department of Administrative \\ and Labor Law \\ FSBEI HE «South-West State \\ University» \\ Kursk, Russia \\ vorontsov.a.l@mail.ru
}

\author{
Vorontsova E.V. \\ Department of Financial Law, \\ Constitutional, Civil and \\ Administrative Proceedings \\ FSBEI HE «South-West State \\ University» \\ Kursk, Russia \\ proskyrinae@mail.ru
}

\author{
Tarasov Yu.A. \\ Department of Civil Law \\ FSBEI HE «South-West State \\ University» \\ Kursk, Russia \\ vorontsov.a.l@mail.ru
}

\author{
Balashova T. N. \\ Department of Civil and Business \\ Law \\ FSBEI HE «Yelets State \\ University named after I.A. \\ Bunin» \\ Yelets, Russia \\ proskyrinae@mail.ru
}

\begin{abstract}
The research is devoted to the analysis of the role and significance of the church in preserving the spiritual health of Russian society. Noting the severity of social problems facing the society, the authors express the idea that the solution of this problems impossible without the allunifying idea, which can act as a generator of socially useful activity. In turn, the ideology crisis of modern society, which based on the cult of material consumption and carnal pleasures, clearly shows the importance of problems of moral culture and spirituality. According to the authors it is necessary to look for a recipe of salvation from the further degradation of public consciousness and the destruction of our society in the sphere of moral culture.
\end{abstract}

The main thesis of the authors is the idea that the moral recovery of Russian society is possible on the way to his return to religion. In this article the authors substantiate this thesis in detail and proved the necessity of a single moral principle, which should cover all human relations. In the opinion of the authors religion give a person necessary moral principle, because only religion irrespective of denominations preaches values that are customary called eternal because of their stability and reflection of the historical experience and culture of a particular nation. The article concludes that only strong and united moral principles can really unite different people into a single society. In this regard, the activities of religious organizations that relay these foundations acquire special significance in Russia, since it facilitates the integration of Russian society and normal socialization of individual.

The article provides a brief retrospective analysis of the interaction of the state and the church in Russia, indicates areas of cooperation between the state and the church at the present time. It is noted that the state and the church are the traditional institutions of integration of Russian society into a single society. It is emphasized that the positive interaction of the state and the church is not only a condition for the stability of civil society, but also a condition for its spiritual health, and consequently - its resistance to external ideological influences. The article emphasizes the need for a balanced state policy towards religious organizations and the need to establish clear legal boundaries of their activities as a condition for the realization of the positive potential of religion as an important institution of socialization.

Keywords: state, church, morality, socialization of the person, moral principle, moral values, spiritual health, Christian morality, Russian Orthodox Church, civil society, religion, faiths, religious organizations, spirituality.

\section{INTRODUCTION}

The Russian society now faces a number of tasks and from its solution depends further development of society in the present and future. These tasks are very difficult, because they cover a wide range of economic, political and social issues. The additional complexity, in our opinion, is attached to the fact that their solution in modern circumstances is impossible without the development of new ideals, without a generating idea. Hence, the problems of moral culture and spirituality acquire special urgency. In turn, the discussion of the problem of spirituality and moral health of our society is one of the most urgent tasks of the humanities.

The problem of spirituality is the problem of a person's going beyond the narrow-empirical being, overcoming oneself in the process of renewal and improvement. It is the ascent of the individual to his ideals, values and reliance on them in the course of his life. Therefore, this is a problem of life creation as a mental basis of life. For generations of Russian people, this problem was concentrated in the search for "conscience", which served as their internal basis for their selfdetermination. Let us note that conscience is a moral category, and morality is a defining part of the spiritual culture and spiritual health of the individual. "Morality is the first value, the fundamental principle of the spiritual life of people is an absolutely necessary condition for all human spirituality" [1]. 
Morality presupposes a certain system of values. The spiritual state of society and its prospects depend on what values is the basis of public morality. The crisis of ideology, evident in many modern societies, based on the cult of material consumption, makes us rethink the value orientations of these societies. As practice has shown, individualism and self-affirmation, do not contribute to the integration of people into single society, but on the contrary, they split it into separate warring groups, easily vulnerable due to their spiritual disunity.

It seems to us that the crisis, experienced by Russia for a long time, is largely caused precisely by the loss of traditional moral values, morality subordination to utilitarian political and ideological interests. It is becoming increasingly clear that it is not enough to overcome political, economic and legal transformations. It is necessary to form a new worldview that can unite and spiritually improve our nation.

Integration of various national and social groups into a single society in Russia for many centuries was provided by two institutions - the state and the church. Namely the church was the guardian of traditional moral values, which the state supported, then rejected. The result of many years of domination of official atheism is known. Thank God, we are witnessing the spiritual revival that is taking place in Russia at present; however, it is impossible without access to the spiritual values of our people. For the majority of the population, these spiritual values are determined by Orthodoxy. At one time, Patriarch Alexey II said: "Without renewing the traditional beginnings of Russian life, one can only completely and irrevocably squander all the fruits of the centuries-old works of previous generations" [2]. At the same time, we shouldn't forget that Russia, according to the Constitution, is a secular state that doesn't give it the opportunity to interact with traditional faiths in the previous (existing before 1917) form, by declaring one of the religions as a state (main) religion. However, the need for such interaction is obvious, since the needs of our spiritual revival and unity require this.

In our work, we will try to analyze the role of religious organizations (primarily the Russian Orthodox Church) in preserving the spiritual health of Russian society and assess their significance as an institution for the socialization of individuals.

We want to warn the reader that using the concept of "church" in our work, we also mean those denominations in which it as such is absent - Muslims, Buddhists, etc. At the same time, when we talk about the moral values of religion, we mean, first of all, the moral values of Orthodoxy, taking into account its prevalence among the majority of the population, and also taking into account the special role of Orthodoxy in the history of the Russian state.

\section{MORALITY AS THE BASIS OF SPIRITUALITY OF SOCIETY}

First of all, it should be noted that the problem of spirituality is not only an indicator of the level of perception by a person of the world around him, his deep relation to other people, to society as a whole and to himself. This is also the answer to many fundamental questions that a person sooner or later asks himself: who am I, what is my place in this world, for what I live, what is the meaning of my life, what values should determine my life's path and all my activities. The spiritual crisis of the last decades only aggravated these issues. There is an urgent need to improve the spiritual sphere of our society, to revive its moral foundations, thanks to which it was formed and developed.

In the minds of many Russians now ingrained idea that moral improvement of society is possible in the way of his return to religion. This position, in our opinion, is not groundless. The religious morality that prevailed for a long time atheistic ideology is contrasted with religious morality, which, unlike others, has passed the test of time and proved to be a reliable basis for the spiritual renewal of the Russian state. At the same time we must remember that for the state as an organization of power, practical significance is not due to religion in itself, but to the moral state of society that it engenders. Outside the framework of the state government cannot exist and perform their functions. This circumstance forces the state to use religion and cherish it.

To be objective, we note that not every state has always carefully treated the religious traditions of its population. However, historical experience and the realities of the present time show that neglect of religion doesn't lead to anything good. The resulting spiritual vacuum is rapidly replaced by moral attitudes, which often have a destructive character.

Given the fact that "morality is at the heart of spirituality" the particular importance have the fact what moral principles the person adhere to. After all, the possession of the mind and will does not make man a spiritual being yet. In this he only differs from the animal. The carnal inclinations and material interests can prevail in a person. There is the power of the spirit, the spiritual freedom of the individual to suppress them and this power is given to man by this religion. At the same time, the church has a twofold task: to inspire respect for the law and power, and to inspire the authorities with respect for human freedom (primarily spiritual freedom). Both decisions should be based on a single moral principle, which cannot be in the church - one, but in public life - the other. There cannot be separate secular moral principle and spiritual moral principle. Single moral principle must embrace all human relations - personal, family, political, economic and other. A truly strong link between power and the people is possible only at a moral beginning. Only strong and united moral principles actually unite different people into a single society. The church, irrespective of a particular confession, preaches these foundations, which in many respects are a reflection of the historical experience and culture of a particular nation. Thus, from the point of view of the interests of the state, all the activities of the church in the broad sense 
are reduced to the upbringing of the individual. In Orthodoxy and other Christian faiths, this "educational process" is carried out primarily through people who are recognized as saints in public opinion. They are the moral guide for the rest of society. A man builds his spiritual organization, seeking at least in some ways to resemble them (by observing their commandments, and not by blind imitation). Thus, the church forms the moral basis of the personality, which is its guide on the path of life. As the distinguished Russian jurist and philosopher I.A.Ilyin wrote: "The people create. The state rules. The Church teaches" [4]. These words, in our opinion, best reflect the interconnection and interaction in society of such socialization institutions as the state and the church.

AN ANALYSIS OF THE EXPERIENCE OF INTERACTION BETWEEN THE STATE AND THE CHURCH IN RUSSIA

The history of the relationship between the state and the church in Russia is full of dramatic events. The periods of fruitful cooperation were followed by periods of open rivalry and confrontation. The church has repeatedly tried to subjugate the state, which in turn actively struggled to get out of the influence of the church. Anyway, the history of the Russian state and the Russian Orthodox Church is inseparable, their social interaction has a thousand-year roots.

The very creation of statehood in Russia is directly connected with Orthodoxy. Many historians believe that the christening of Rus in 988 in the reign of Saints Olga and Vladimir is the starting point of the future Russian state. Unfolding his apostolic awareness among people with pagan religion Orthodoxy changed and enriched folk spirit, turning it from immorality and selfishness of primitive beliefs to the Christian principles of justice, goodness and love of neighbor.

Called by the power of the first Orthodox princes to cooperate in social construction, the church did much to spread and strengthen the principles of Christian morality in the state: it transformed the primary social unit of society-the family, replacing pagan polygamy with monogamy, banning the purchase and theft of brides; changed the family structure, recognizing the woman's right to a full-fledged personality, which undoubtedly raised the status of wife and mother [5].

The Church in Rus limited exploitation, introduced equality of free people before the law. Orthodoxy was the unifying principle for the population of scattered principalities in the difficult era of the Mongol-Tatar yoke and it saved our national identity from being taken over by foreign culture. Eliminating the chaos of tribal customs on the basis of Christian solidarity and brotherhood, Orthodoxy created a single Russian people, who won the Kulikovo battle.

Thus, it is impossible to overestimate the influence and significance of the preaching work of the church for the morality of Russian people. The church created a state ideology, the spiritual foundations of the Russian state, which are mainly Orthodox acted. We tend to agree with the words of the prominent Russian scientist L.A. Morozova that "the church had a great influence on the economic and political life, on the way of life of the population, on interstate relations" [6]. In the opinion of another Russian scientist, R.V. Puzikov, this was due to the fact that "it was precisely Orthodoxy, with its teachings and ideas about good and evil, justice and worldview, professed by many people around the world, that helped to find answers to those vital questions, which worried believers "[7].

On the socio-political plane for a long time, the Russian Orthodox Church was a single system with the state. One did not exist, and could not exist separately from another. The authority of the monarchs was supported by the authority of the church, and the church received state support and acted as a mechanism that formed a public outlook. For many centuries the church in Russia, and not only the Orthodox church, was an energetic guide of feudal order, gave them a sacred character, from the standpoint of religious dogma, justified the supremacy of state power.

The state tried to completely subordinate the church and make it part of the state apparatus with the assertion of absolutism in Russia (which was done under Peter the Great, who created the Holy Synod instead of the institution of the patriarchate). In turn, the further development of state-church relations and the formation of bourgeois social order were accompanied, as a rule, by the requirement of separation of church and state. Relation to religion became a private matter for every person.

In our opinion, the aspiration of the bourgeois states to separate the church from them laid their desire to deprive the church of the monopoly in fulfilling the ideological and socially integrative function. The bourgeois state understands that the ideology of the church, with its support for Christian morality, does not correspond to the new morality of bourgeois society and realizing that the church has a huge potential for ideological influence on the citizens' consciousness, chose the separation of church and state, proclaiming the latter as secular.

The socialist state went even further. Atheism became the official state ideology in the USSR. In fact, the state banning traditional religious cults, could not give the society a proper replacement, which would help him to endure all deprivation of life. Replacing the ideology of traditional faiths moral code of the builder of communism has failed.

At present, freedom of conscience and religion is proclaimed and guaranteed in the Russian Federation (Article 28 of the Constitution of the Russian Federation). Everyone has the right to profess individually or in community with others any religion or not to profess any. In addition, everyone has the right to freely choose and disseminate religious beliefs and act in accordance with them. There is a religious pluralism, legislated in Russia.

As for the church, its status has changed significantly. The Russian Federation is a secular state in accordance with the Constitution (Article 14 of the Constitution of the Russian 
Federation). This means that no religion can be established as a state or compulsory religion. In conditions multiconfessional character of our state, this is very important, since this provision excludes an occasion for religious hostility because of the disadvantaged position of various confessions. In addition, Part 2 of Article 14 of the Constitution of the Russian Federation establishes that religious associations are separated from the state and are equal before the law. Among other things, this means that the church (in a broad sense) has become a full-fledged institution of civil society. It is its independent element, recognized and respected by the state.

If we return to the Russian Orthodox Church, it should be noted that in the 76 years that have passed since the February Revolution of 1917, its status in the Russian state has changed three times: from the state institution of the period of the Most Holy Synod to independence and the resumption of the patriarchate during the Provisional Government, a complete ban on any public activity in the Soviet period of Russian history and, finally, the free functioning of the Russian Orthodox Church in the framework of a legally constituted the captive separation from the state on a par with other faiths. It seems to the authors of this article that such legal status of the Russian Orthodox Church only contributes to the realization of its true purpose - the upbringing of Christian morality.

By its activity the church shows that even when the church is separated from the state, there is no complete isolation between these institutions. During the years of persecution, the church in our country has not forgotten how to mediate between society and the state. In carrying out its mediatory mission, the Church has always sowed good and eternal, preaching the social harmony and orderliness. Thus, in the secular state, which is modern Russia, the Russian Orthodox Church, having gained independence from state power, has thereby received the full opportunity for the mission entrusted to the church by Christ.

These tasks are currently being implemented in a wide range of social relations, which are areas of cooperation between the state and the church. This is peacekeeping at the international, interethnic and civil levels; preservation of the moral health of society; spiritual, cultural and patriotic education and upbringing; charity; protection of historical and cultural monuments; health; care for people in prison and other areas. It is this interaction that allows the church to realize its spiritual and moral integrative potential and act as one of the pillars of Russian statehood.

\section{THE MORAL AUTHORITY OF THE CHURCH AS THE BASIS OF ITS LEGAL POSITION IN RUSSIA}

The awareness of the modern Russian state of the main purpose of the church as a spiritual mentor of the society is manifested in the sphere of their property and financial and legal relations. The goal of religious organizations in the field of spiritual education and upbringing clearly recognized by society affects the legal status of the latter, and most importantly - their social (consider moral) authority, which, in turn, generally determines the attitude of the state power to them.

According to the current legislation, religious organizations in Russia are legal entities. According to their legal status, they are non-profit organizations that don't pursue profit-making as the main goal of their activities and don't distribute the profit among their participants (article 50, article 117 of the Civil code of the Russian Federation). The abovementioned provisions of the Civil code of the Russian Federation clearly refer to the detailed regulation of the activities of religious organizations (as non-profit) to the relevant Federal law, which is the Law "On non-profit organizations". This follows from the generally accepted logic of legal regulation, which is based on the generic object of regulation. And this Law contains a provision on religious organizations, but it is essentially removes religious organizations from the scope of this act. It would seem that this is an obvious paradox. At the same time, there is no legal paradox taking into account the specifics of religious organizations as organizations created to meet spiritual or other intangible needs. This specificity was taken into account by the Russian legislator, who established in article 6 of the Federal law "On non-profit organizations" a reference rule, which states that the peculiarities of the legal status, creation, reorganization and liquidation of religious organizations, management of religious organizations are determined by the Federal law on religious organizations.

Being interested in self-financing of the activities of religious organizations, the state has legally granted them the right to carry out not only cult activities, but also other, including entrepreneurial activity. The main condition for such activities should be the use of its results to achieve the main goal of the religious organization.

The Russian state deliberately puts religious organizations in a special position compared to other public and non-profit organizations: religious organizations have a number of tax benefits axes on property, value added, profit, land, etc.), get for free use or property land, property for religious purposes. A number of other non-profit organizations also have benefits. However, the provision of benefits in respect of them is in the nature of the" response» of the state for socially useful activities that allow saving budgetary funds. As for religious organizations, we are deeply convinced that their privileges are nothing more than a moral duty of the state, which consists in allocating a certain part of public wealth to satisfy the spiritual needs of citizens.

At the same time, there are problems in the issue of state support for religious organizations, including financial assistance, that need to be resolved. We are talking about the allocation of budget funds. The fact is that the procedure for determining the amount of budget funds allocated to the needs of religious organizations and the proportions of their distribution among the faiths are not settled at all. This fact creates a situation in which public funds can be allocated 
exclusively selectively, based on the religious preferences of representatives of state power. It seems that such practice in the conditions of the multi-confessional nature of the Russian state will not contribute to the stability of society. It may happen that the state supporting religious organizations as an institution of social integration will make them an instrument of social division, pursuing an ill-conceived policy in the field of their financial support.

One way or another, but in any case, legislative work is required to improve the legal framework for the relationship between state structures and the Church. This sphere of social relations is too important for society to leave it out of due legal attention. Spirituality is not a legal concept, but there is no doubt that the relations arising in the sphere of formation and satisfaction of spiritual needs require their regulatory regulation. In modern conditions of total legalization, only a clear legal framework for activities will allow the Church to fully realize its mission as a spiritual pastor of civil society.

\section{CONCLUSION}

The analysis of the problem identified by us allowed us to draw the following general conclusions:

1. The state and the church are historically traditional institutions for the integration of Russian society into a single society. This social interaction still largely ensures the stability of the entire civil society system in Russia, since the church, on the one hand, is the relay of stable spiritual values passed from generation to generation without exceptions and transformations, and the state, on the other hand, supports these values by creating legal conditions for their dissemination in society

2. Since the inception of statehood in Russia, the servants of the church have invariably exercised the function of spiritual unification of society. This is the main social role of the Church institution in our country, but not unique role. Providing the unity of society on the basis of generally accepted spiritual values, the church at the same time actively participated in the reproduction of the spiritual needs of man. This made it possible to avoid social disintegration, dehumanization of public life in the course of inevitable sociocultural transformations. Thus, the disintegration of Russian society was prevented.

3. The positive interaction of the state and the church is not only a condition for the stability of civil society, but also a condition for its spiritual health, and consequently - its resistance to external ideological influences. This is due to the transcendental nature of the social values preached by the church. It is these values that constitute the spiritual core of the entire Russian people.

4. In the conditions of the development of social competition, the universal spread of individualism as a new social ideology, it is necessary to realize and take for granted the priority of the church in the spiritual sphere, in the matter of spiritual integration. In turn, spiritual integration will become the basis of social integration - so necessary for Russia. Integration is based on the spiritual experience of numerous generations that have carried through the ages the ideas that make up the basis of human civilization.

5. An urgent task of any secular state is to establish clear legal boundaries of the activities of religious organizations as a necessary condition for the free realization of the spiritual needs of the population. Only a clear legal regulation of the status, organizational forms and methods of activity of all religious organizations, based on the principle of legal equality of any traditional confessions, can create the necessary emotional and moral atmosphere in society that allows to realize the entire positive potential of religion as an institution of social outlook and socialization.

At the same time, in the provision of state support to various religious associations, it is necessary to take into account the cultural, historical, ideological and other features of state-Church relations in a particular region, as well as the role or importance of the religious factor in the social life of a particular ethno-cultural community.

6. In the context of actively used in politics the principle of tolerance (including religious tolerance) should be taken into account not only the interests of the minority population, but also the interests of the majority population. A perverted interpretation of this principle only in the context of tolerant (favorable) attitude towards the minority to the detriment of the interests of the majority, in the religious sphere, as in no other, can split society, create artificial antagonism between representatives of different religions.

Realizing the importance of the religious factor in the life of Russians, the state power in its relations with traditional confessional associations should proceed from the priori recognition of the cultural, historical and moral value of the spiritual practices. In our opinion, this is the true meaning of cultural and religious tolerance perceived by the world community as the fundamental principle of the functioning of modern society.

\section{REFERENCES}

[1] S.F. Anisimov «On the primacy of morality in the structure of human spirituality», Bulletin of Moscow University. Ser. 7, Philosophy. № 1, 2001, pp. 26-36.

[2] Christmas readings in 1997. From the words of Patriarch Alexy II at the opening of the $\mathrm{V}$ International Christmas Educational Readings // http://patriarh-i-narod.ru/slovo-patriarha/rozhdestvenskieobrazovatelnye-chteniya/261-rozhdestvenskie-chteniya-1997-goda

[3] L.V. Veselovskaya «Morality and religion», Collected materials of the International Scientific and Theoretical Conference on the 250th anniversary of the birth of Seraphim Sarovsky "Social partnership of the state and the church - an objective condition for the stability of the political system of civil society." Kursk, 2004, pp.429-434.

[4] I.A. Ilyin «Lonely artist», Articles, speeches, lectures, M.: Art, 1993. P. 348 
[5] A.L. Vorontsov «The Role of Orthodoxy in the Life of Russian Society in the Conditions of Secular State Character» Izvestiya YugoZapadnogo Gosudarstvennogo Universiteta. Series: History and Law. 2012, № 2-1, pp. 140-144.

[6] L.A. Morozova «The state and the church: the features of the relationship», Journal of State and Law, 1995, № 3, pp.86-95.
[7] R.V. Puzikov, Zh.V Knyazeva «The secular state and the Orthodox Church: the features of the relationship», Collected materials of the International Scientific and Theoretical Conference dedicated to the 250th anniversary of the birth of Seraphim Sarovsky "Social partnership of the state and the church is an objective condition for the stability of the political system of civil society." Kursk, 2004, pp.239-243. 